\title{
ANALYSIS OF THE KEYNESIAN THEORY OF EMPLOYMENT \\ AND SECTORAL JOB CREATION: THE CASE OF THE SOUTH AFRICAN \\ MANUFACTURING SECTOR
}

Thomas Habanabakize, Ph.D. Candidate

School of Economic Sciences

North-West University, South Africa

e-mail:tomhaban12@gmail.com

Paul-Francois Muzindutsi, Ph.D., Senior Lecturer

School of Accounting, Economics and Finance

University of KwaZulu-Natal

University Road Westville

Private Bag X 5400, Durban 4000, South Africa

e-mail: paul.muzindutsi@ukzn.ac.za

Received 25 September 2017, Accepted 27 March 2018

\begin{abstract}
The manufacturing sector is one of the backbones of the South African economy, and yet is one of the economic sectors facing challenges in job creation. This study analysed the long-run and short-run effects of aggregate expenditure components on job creation in the South African manufacturing sector. A Vector Autoregressive (VAR) with Johansen co-integration approach was used to analyse quarterly data from 1994 to 2015. The findings are that there is a long-run relationship between aggregate expenditure and job creation in the South African manufacturing sector, with government and investment spending being the major components of aggregate expenditure that create jobs in the South African manufacturing sector. Conversely, consumption spending destroys jobs in the manufacturing sector, while net exports have no significant effect on job creation. The short-run relationship between variables was not significant. Recommendations are that more effort should be put into investment spending, and government should spend more on investment than on consumption spending - in order to increase job creation in the manufacturing sector.
\end{abstract}

Keywords: Keynesian model, job creation, unemployment, manufacturing sector, South Africa

JEL classification: D20, E20 


\section{Introduction}

Manufacturing is one of the major sectors that contribute to economic growth in general, and employment particularly. The positive side of the manufacturing sector in creating jobs emanates from the combination of human capital and entrepreneurship - to produce goods that can be sold, used as intermediates or final products (Majumdar, Borbora, 2015). Thus, the manufacturing sector can enhance job creation through labour-intensive production. In the South African context, the manufacturing sector is one of the major economic sectors. It refers to the process of employing labour and some other tools to produce semi-finished (intermediaries) and final goods that can be sold within domestic or international markets (Small Enterprise..., 2012). The South African Statistics Service (StatSA, 2015) distinguishes three types of products in the manufacturing sector: food and cloth products; beverages and tobacco; and secondary production of furniture (set of sport products, jewelry, and stationary and music instruments). Employment in this sector is usually measured using the index of total number employment or jobs (SARB, 2015).

Although different theories and studies assert that manufacturing sectors play a major role in employment creation - no study has tested the effect of the Keynesian theory of employment (through aggregate expenditure) on the South African manufacturing sector. Thus, there is a need to assess how aggregate expenditure can be used to create and improve or destroy employment in the South African manufacturing sector. The aim of this study is to determine which component of aggregate expenditure contributes more to job creation in the South African manufacturing sector.

\section{Review of empirical studies on aggregate expenditure and job creation}

In the initial Keynesian theory of employment, demand and spending are considered as a job creation engine for high demand, and spending leads to more supply which requires more labour (Keynes, 1936). Nonetheless, various scholars challenged this theory. For instance, analyzing what should be the solution to Spain's higher rate of unemployment, Afonso and Sorolla (2012) found that the implementation of the Keynesian aggregate expenditure model could destroy more existing jobs than create new ones. The same conclusion was reached by Coenen and Straub (2005) in their study assessing whether government spending, as one of the aggregate expenditure components, could crowd-out consumption in the private sector in the European zone. They found that government spending does not have a strong impact on private consumption. The money spent by government can increase household consumption 
(demand for goods and services) or be used to subsidize producers (resulting in lower cost of production) - suggesting that government spending can increase hiring ability from the private sector. Furthermore, analyzing the effects of spending on consumption in the USA, Galí, López-Salido and Vallés (2005) found that government spending increased both wages and employment. These controversies around the effect of spending on employment are indications that the Keynesian aggregate expenditure model may work in favour of employment in some countries, while it might be a misfortune for others. The next section presents different findings obtained by applying the Keynesian aggregate expenditure model, to determine its link to total employment and job creation.

\subsection{Household Consumption Expenditure and Job Creation}

In respect of the Keynesian theory, demand creates its own supply, and henceforth the more goods and services are demanded by households for consumption - the higher is the quantity produced, and, as a result, the higher the labour demand, ceteris paribus (Chamley, 2014). There is a positive relationship between employment growth and a household's consumption (Bentolila, Ichino, 2000), as household consumption contributes more to economic growth - which is the engine of job creation (Gurgul, Lach 2011). Although many strategies can be employed to create jobs, Bentolila and Ichino (2000) and Lamo, Pérez and Schuknecht (2007) gave more credit to household consumption for its abilities to stimulate and create more jobs without causing other negative impacts on the general economy. In this regard, Stanlib (2013) considered consumption spending as the backbone of the economy in South Africa, because it has a considerable effect on the country's gross domestic product (GDP). Contrary studies by Schettkat and Salverda (2004) found that the link between job creation and household consumption depends on many factors. Henceforth, depending on a specific factor, household consumption can create or destroy jobs, and in some cases there might be no relationship between consumption spending and job creation. Having a job does not necessarily imply consumption growth, as in some cases, an employee might choose to increase saving over consumption spending (Emilia, 2008). Besides, technological production growth and the consumption of imported goods and services may also lead to job destruction (Autor, Dorn \& Hanson, 2013). When households increase the consumption of imported goods and services, domestic production declines - as a high demand for imported goods creates more jobs within the exporting country (Toossi, 2002). In other words, the consumption of imported goods tends to destroy domestic jobs (Emilia, 2008). The linkage between net exports and job creation is discussed next. 


\subsection{Total Net-Exports and Job Creation}

Net export is another component of aggregate expenditure that can play an important role in job creation. Job creation depends on the dynamic in the labour and in some instances unemployment is of markets failure (Keynes, 1936). If the quantity demanded is higher than the production capability of existing labour, new workers have to be hired to facilitate equilibrium between demand and supply (Tcherneva, 2008). Consequently, more demand from foreign buyers may lead to more supply in a domestic country, and the increased supply involves more demand for labour - other factors being held constant (Dizaji, Badri, 2014; Bobeica, Esteves, Rua, Staehr, 2016). The role of exports in the economy is not just limited to the creation of direct jobs, but also stimulates new jobs and protects existing ones indirectly. Countries with a higher level of exports are less likely to face unemployment growth (job losses), for, beyond job creation, exports sustain existing jobs. In California for example, exports are considered to be the engine for growing and sustaining jobs (Tschetter, 2010). The rise in exports from manufacturing products has been and is still considered the engine for employment growth in countries like China, Indonesia, Japan, and Korea (Kiyota, 2016). The jobs created by manufacturing exports affect not only the manufacturing sectors, but also employment in other sectors like agriculture, mining, and construction - which provide input for manufacturing (Nguyen, 2015). Consequently, there is a positive linkage between manufacturing export growth and job creation within the manufacturing sector and in some other sectors (Athukorala, Santosa, 1996). Thus, the exports related to manufacturing products play a key role in increasing the number of jobs, even for low or unskilled job seekers, and in the informal sector (Fukase, 2013).

Although the afore-mentioned studies suggest a positive relationship between exports and job creation, Feenstra and Hong (2007) argued that in the Chinese economy between 2000 and 2005, domestic demand created more jobs than total exports. Moreover, an increase in exports may have an inverse relationship with job creation if the exported goods and services are a result of the use of machinery. In other words, the export growth from technology improvement might destroy more jobs than it creates - if productivity is based on capital-intensive or the increased number of working hours per existing worker (Kiyota, 2011; Sousa, Rueda-Cantouche, Arto, Andreoni, 2012). Furthermore, if total export growth leads to labour wage and per capita productivity growth, the demand for labour would remain constant (Said, Elshennawy, 2010). Besides the positive and negative effects of exports on job creation, the study by Los, Timmer and de Vries (2015) on exports and employment in China, found that exports might increase or leave employment levels unaffected. The study revealed that if foreign demand rises together 
with the existing domestic labour productivity, the effect of export growth on employment remains unchanged.

\subsection{Government Spending and Job Creation}

The effect of government spending on job creation has been an ongoing topic through the decades. Studies of Finn (1998), Amjad (2005), Blanchard and Perotti (2002), and Holden and Sparrmany (2016) on how government expenditure decisions affect employment, found that increased government spending led to economic growth which thereafter increased the level of employment. The more government spends, the lower is the unemployment rate, and the higher is the number of new jobs created (Ramey, 2012). Other studies (Kenyon, 1997; Cray, 2011; Leigh, Neill, 2011; Maisonnave, Mabugu, Chitiga, Robichaud, 2013) found that government spending on infrastructure should be the key to job creation. Consequently, government spending in this sector is considered to be one of better strategies to grow employment.

That said, Loizides and Vamvoukas (2005), Afonso and Sousa (2012), and Bertolis and Hayes (2014) found that government expenditure does not contribute more towards economic growth. If government spending does not aim at economic growth - the relationship between job creation and government spending would eventually be negative (Mahmood, Khalid, 2013). Furthermore, the effect of government spending on job creation is more effective during sluggish economic conditions than when the economy is booming (Beard, Ford, Kim, Spiwak, 2011). Therefore, the outcome of government spending on job creation is subjected to the economic cycle.

\subsection{Investment Spending and Job Creation}

Investment spending - which is regarded as gross fixed capital formation in the South African context - should not, from a macroeconomic perspective, be treated as just a process of improvement in capital accumulation; rather it is one of four aggregate expenditure components; which are more effective for job creation (Munnell, 1992). The hypothesis of a positive relationship between job creation and investment spending was proved correct by the study of Psaltopoulos, Skuras and Thomson (2011) on the relationship between investment and employment in the EU, which found that in EU rural areas more jobs were created through private investment spending. The study by Shi and Michelitsch (2013), on the role of manufacturing in employment across 100 countries, proved that more jobs were created through investment spending. In the same context, the study by Tschetter (2010) on the benefits of jobs 
in manufacturing found that employees are less likely to abandon their jobs in the manufacturing sector than in other sectors.

There is a strong cause-effect relationship between investment spending and employment - as the former is one of the paramount strategies to create jobs, while the latter can cause the former. The alteration of each of the two (employment and/or investment) causes direct and mutual effects. Iacovoiu's (2012) Romanian study found that investment fluctuations in Romania between 2004 and 2012 were associated with oscillations in the employment rate. Thus, a low level of investment spending leads to high joblessness and vice versa. Dinh, Palmade, Chandra and Cossar (2012) and Habanabakize and Muzindutsi (2015) found that for South Africa and other sub-Saharan countries, more jobs could be created if the degree of investment spending in the manufacturing sector was increased.

Contrary to the afore-mentioned studies that recognise a positive relationship between investment spending and employment, the study by Maisonnave et al. (2013) on the effect of investment spending on job creation, found that investment spending sometimes is a solution for joblessness. The reason behind this idea is that investment spending that creates jobs in one sector might be done at the expense of job creation in other sectors. Moreover, Nicholson and Noonan (2014) argued that investment spending might have small effects on employment in manufacturing because of its higher level of employment turnover caused by technology improvement - which reduces labour demand. Investment spending on technology in the local manufacturing sector improves competitiveness and productivity. However, it also destroys jobs because it replaces or reduces labour demand (Rotman, 2013).

\section{Data description and econometric modeling}

In order to determine the effect of aggregate expenditure and job creation on the manufacturing sector, this study employed a quarterly time series for the 21-year-period from the first quarter of 1994 to the fourth quarter of 2015. The selected data are seasonally adjusted and the choice of data timeframe was motivated by the availability of the data. Employment was used as a proxy for job creation in the manufacturing sector; it was obtained from the total employment index, and total employment is the difference between the labour force and the total number of unemployed people in the labour force. Government spending comprises spending on salaries and wages, goods, and services, and also on different governmental departments. It is measured in billions of Rand (SARB, 2015). The final expenditure by households comprises all expenses of households on goods and services - including the expenses of non-profit 
organisations - by household. The fourth variable was investment spending, which is known as real gross capital formation in the South African context. It comprises private and public investment, and is measured in millions of Rand. Lastly, the net export is the difference between total exports and total inputs, and it is also measured in millions of Rand (SARB, 2015).

To analyse the relationship between the dependent and independent variables, all variables were transformed into a natural logarithm. This was done with the intention of determining the elasticity of job creation within the manufacturing sector - in response to the change in aggregate expenditure. Notwithstanding this, since there is no logarithm of negative numbers (values), the net export could not be transformed, as some of its series are negative. Different methods and techniques can be used to determine the co-integrating relationship between the variables, including: the residual-based approach of Engel and Granger (1987) and the maximum likelihood-based technique of Johansen and Julius (1990) and Johansen (1992). These approaches may have different advantages depending on the integration order of variables. The maximum likelihood suggested by Johansen and Julius is more advantageous when the analysed variables are of the same integration. Since the variables in this study are all I (1), the results of cointegration were obtained using the Johansen test of cointegration.

\section{Model specifications}

To determine the interaction between South African aggregate expenditure and job creation in the manufacturing sector - the following VAR model was formulated:

$$
\begin{aligned}
& \operatorname{LEMAN}_{t}=C_{1}+\sum_{i=1}^{k} \beta_{1 i} \operatorname{LEMAN}_{t-i}+\sum_{i=1}^{k} \gamma_{1 i} \operatorname{LCONS}_{t-i}+\sum_{i=1}^{k} \delta_{1 i} \operatorname{LGOVES}_{t-i}+ \\
& +\sum_{i=1}^{k} \theta_{1 i} \text { LINVES }_{t-i}+\sum_{i=1}^{k} \varphi_{1 i} N E X P_{t-i}+e_{1 t} \\
& \operatorname{LCONS}_{t}=C_{2}+\sum_{i=1}^{k} \beta_{2 i} \operatorname{LEMAN}_{t-i}+\sum_{i=1}^{k} \gamma_{2 i} \operatorname{LCONS}_{t-i}+\sum_{i=1}^{k} \delta_{2 i} \text { LGOVES }_{t-i}+ \\
& +\sum_{i=1}^{k} \theta_{2 i} \operatorname{LINVES}_{t-i}+\sum_{i=1}^{k} \varphi_{2 i} N E X P_{t-i}+e_{2 t} \\
& \text { LGOVS }_{t}=C_{3}+\sum_{i=1}^{k} \beta_{3 i} \text { LEMAN }_{t-i}+\sum_{i=1}^{k} \gamma_{3 i} \text { LCONS }_{t-i}+\sum_{i=1}^{k} \delta_{3 i} \text { LGOVES }_{t-i}+ \\
& +\sum_{i=1}^{k} \theta_{3 i} L_{I N V E S_{t-i}}+\sum_{i=1}^{k} \varphi_{3 i} N E X P_{t-i}+e_{3 t}
\end{aligned}
$$




$$
\begin{aligned}
\operatorname{LINVES}_{t}=C_{4}+ & \sum_{i=1}^{k} \beta_{4 i} \text { LEMAN }_{t-i}+\sum_{i=1}^{k} \gamma_{4 i} \text { LCONS }_{t-i}+\sum_{i=1}^{k} \delta_{4 i} \text { LGOVES }_{t-i}+ \\
& +\sum_{i=1}^{k} \theta_{4 i} \text { LINVES }_{t-i}+\sum_{i=1}^{k} \varphi_{4 i} N E X P_{t-i}+e_{4 t} \\
\operatorname{LNEXP}_{t}=C_{5}+ & \sum_{i=1}^{k} \beta_{5 i} \text { LEMAN }_{t-i}+\sum_{i=1}^{k} \gamma_{5 i} \operatorname{LCONS}_{t-i}+\sum_{i=1}^{k} \delta_{5 i} \operatorname{LGOVES}_{t-i}+ \\
& +\sum_{i=1}^{k} \theta_{5 i} \operatorname{LINVES}_{t-i}+\sum_{i=1}^{k} \varphi_{5 i} \operatorname{NEXP}_{t-i}+e_{5 t}
\end{aligned}
$$

where:

$L E M A N_{t}$ - natural logarithm of employment in the manufacturing sector at time $t$,

$L_{C O N S}$ - natural logarithm of household consumption spending at time $t$,

$L G O V S_{t}$ - natural logarithm of government spending at time $t$,

LINVES $_{t}$ - natural logarithm of investment spending at time $t$,

$N E X P_{t} \quad-$ Net export spending at time $t$, and

$C_{n}$ indicates the constant; $\beta_{n}, \gamma_{n}, \delta_{n}, \theta_{n}$, and $\varphi_{n}$, represent coefficients; $k$ denotes the number of lags employed; and $e_{1 t}, \ldots, e_{5 t}$ represent the stochastic error terms.

The estimation of the above equations is preceded by the unit root test, in order to ensure the variables' stationarity. If variables are found to be stationary at level or I (1), the VAR analysis is undertaken. However, if variables are not I (0), these are differentiated and the cointegration test is used. The presence of co-integration among variables requires the estimation of Vector Error Correction (VEC). Assuming that one cointegrating relationship exists, the VECM derived from equations 1 to 5 can be represented as follows:

$$
\begin{aligned}
\Delta \text { EMAN }_{t}= & C_{1}+\sum_{i=1}^{k} \beta_{1 i} \Delta E M A N_{t-i}+\sum_{i=1}^{k} \gamma_{1 i} \Delta C O N S_{t-i}+\sum_{i=1}^{k} \delta_{1 i} \Delta G O V E S_{t-i}+ \\
& +\sum_{i=1}^{k} \theta_{1 i} \Delta I N V E S_{t-i}+\sum_{i=1}^{k} \varphi_{1 i} \Delta N E X P_{t-i}+\omega_{1} E C T_{1 t-1}+e_{1 t} \\
\Delta \text { CONS }_{t}= & C_{2}+\sum_{i=1}^{k} \beta_{2 i} \Delta E M A N_{t-i}+\sum_{i=1}^{k} \gamma_{2 i} \Delta C O N S_{t-i}+\sum_{i=1}^{k} \delta_{2 i} \Delta G O V E S_{t-i}+ \\
& +\sum_{i=1}^{k} \theta_{2 i} \Delta I N V E S_{t-i}+\sum_{i=1}^{k} \varphi_{2 i} \Delta N E X P_{t-i}+\omega_{2} E C T_{2 t-1}+e_{2 t}
\end{aligned}
$$




$$
\begin{aligned}
\Delta \text { SOVS }_{t} & =C_{3}+\sum_{i=1}^{k} \beta_{3 i} \Delta E M A N_{t-i}+\sum_{i=1}^{k} \gamma_{3 i} \Delta C O N S_{t-i}+\sum_{i=1}^{k} \delta_{3 i} \Delta G O V E S_{t-i}+ \\
& +\sum_{i=1}^{k} \theta_{3 i} \Delta I N V E S_{t-i}+\sum_{i=1}^{k} \varphi_{3 i} \Delta N E X P_{t-i}+\omega_{3} E C T_{3 t-1}+e_{3 t} \\
\Delta I N V E S_{t}= & C_{4}+\sum_{i=1}^{k} \beta_{4 i} \Delta E M A N_{t-i}+\sum_{i=1}^{k} \gamma_{4 i} \Delta C O N S_{t-i}+\sum_{i=1}^{k} \delta_{4 i} \Delta G O V E S_{t-i}+ \\
& +\sum_{i=1}^{k} \theta_{4 i} \Delta I N V E S_{t-i}+\sum_{i=1}^{k} \varphi_{4} \Delta N E X P_{t-i}+\omega_{4} E C T_{4 t-1}+e_{4 t} \\
\Delta N E X P_{t}= & C_{5}+\sum_{i=1}^{k} \beta_{5 i} \Delta E M A N_{t-i}+\sum_{i=1}^{k} \gamma_{5 i} \Delta C O N S_{t-i}+\sum_{i=1}^{k} \delta_{5 i} \Delta G O V E S_{t-i}+ \\
& +\sum_{i=1}^{k} \theta_{5 i} \Delta I N V E S_{t-i}+\sum_{i=1}^{k} \varphi_{5} \Delta N E X P_{t-i}+\omega_{5} E C T_{5 t-1}+e_{5 t}
\end{aligned}
$$

Where $\omega_{1}$ to $\omega_{5}$ are coefficients of the error correction ECT that captures the adjustment of fluctuations in variables towards the long-run equilibrium. The analysis of VECM was followed by the Granger causality tests, to determine the short-run direction among pairs of variables. To detect the reaction of each variable to its own shocks, as well as the shocks from other variables, the variance decomposition and impulse response were employed. A number of diagnostic tests like heteroscedasticity, autocorrelation, parameter stability, and normality were conducted to ensure the accuracy of the results obtained from the used model.

\section{Results and discussion}

\subsection{Unit Root Test and Lag Selection}

The test for unit root is critical in the VAR model, as its omission may lead to spurious or irrational results. In other words, the results obtained without the unit root test, cannot be trusted or used to form the correct policies. Moreover, the unit root test can serve as a better tool to determine the order of integration of employed variables. In this study, the Augmented Dickey-Fuller (ADF) approach and the Phillip-Perron (PP) tests were used, and the test results are represented in Table 1.

Table 1 displays the p-values of unit root tests for variables. The results indicate that none of the tested variables was stationary at level with or without trend. Since they were not stationary at the level, the second step was to differentiate them, and then they became stationary at the first difference. This suggests that all variables, without exception, are I (1), as represented in Table 1, and both approaches (ADF and PP) reached the same conclusion. 
Table 1. Results of Unit Root Tests (p-values)

\begin{tabular}{|l|l|c|c|c|c|c|c|}
\hline \multirow{2}{*}{ Variable } & Model specification & \multirow{2}{*}{$\begin{array}{c}\text { Lag } \\
\text { order }\end{array}$} & ADF & PP & ADF & PP & Integration \\
& & & levels & levels & $1^{\text {st }}$ difference & $1^{\text {st }}$ difference & order \\
\hline \multirow{2}{*}{ LEMAN } & Intercept & 2 & 0.581 & 0.571 & $0.000^{* *}$ & $0.000^{* *}$ & $\mathrm{I}(1)$ \\
\cline { 2 - 8 } & Intercept \& trend & 2 & 0.559 & 0.453 & $0.000^{* *}$ & $0.000^{* *}$ & $\mathrm{I}(1)$ \\
\hline \multirow{2}{*}{ LCONS } & Intercept & 2 & 0.714 & 0.693 & $0.009^{* *}$ & $0.007^{* *}$ & $\mathrm{I}(1)$ \\
\cline { 2 - 8 } & Intercept \& trend & 2 & 0.375 & 0.789 & $0.031^{* *}$ & $0.038^{* *}$ & $\mathrm{I}(1)$ \\
\hline \multirow{2}{*}{ LGOVS } & Intercept & 2 & 0.950 & 0.989 & $0.004^{* *}$ & $0.001^{* *}$ & $\mathrm{I}(1)$ \\
\cline { 2 - 8 } & Intercept \& trend & 2 & 0.098 & 0.108 & $0.018^{* *}$ & $0.006^{* *}$ & $\mathrm{I}(1)$ \\
\hline \multirow{2}{*}{ LINVES } & Intercept & 2 & 0.716 & 0.680 & $0.000^{* *}$ & $0.000^{* *}$ & $\mathrm{I}(1)$ \\
\cline { 2 - 8 } & Intercept \& trend & 2 & 0.689 & 0.825 & $0.000^{* *}$ & $0.000^{* *}$ & $\mathrm{I}(1)$ \\
\hline \multirow{2}{*}{ NEXP } & Intercept & 2 & 0.805 & 0.648 & $0.000^{* *}$ & $0.000^{* *}$ & $\mathrm{I}(1)$ \\
\cline { 2 - 8 } & Intercept \& trend & 2 & 0.580 & 0.433 & $0.000^{* *}$ & $0.000^{* *}$ & $\mathrm{I}(1)$ \\
\hline
\end{tabular}

** The rejection of the null hypothesis at $5 \%$ level of significance, lag order selected by Schwarz information criterion (SIC).

Source: own elaboration.

However, it was better, before any estimation, to determine the optimal number of lags to be employed by the VAR approach. The information criteria well known in determining the optimal lag length are: Log likelihood (LR) test statistic; Final prediction error (FPE); Akaike information criterion (AIC); Schwarz information criterion (SIC); and the Hannan-Quinn information criterion (HQIC). The lag-section results are shown in Table 2. Three (FPE, SC, HQ) criteria suggested the use of 2 lags, while AIC and LR suggested 8 and 7 lags, respectively. The results of lag-length selection are represented in Table 2.

Table 2. Lag Order Section Results

\begin{tabular}{|c|c|c|c|c|c|c|}
\hline Lag & LogL & LR & FPE & AIC & SC & HQ \\
\hline 0 & $-4,089.09$ & NA & $1.94 \mathrm{E}+38$ & 102.35240 & 102.50120 & 102.41200 \\
\hline 1 & $-3,508.26$ & $1,074.54300$ & $1.80 \mathrm{E}+32$ & 88.45650 & 89.34976 & 88.81463 \\
\hline 2 & $-\mathbf{3 , 4 4 6 . 9 0}$ & $\mathbf{1 0 5 . 8 5 4 3 0}$ & $\mathbf{7 . 2 9 e}+\mathbf{3 1} 1^{*}$ & $\mathbf{8 7 . 5 4 7 3 8}$ & $\mathbf{8 9 . 1 8 5 0 2}^{*}$ & $\mathbf{8 8 . 2 0 3 9 6}^{*}$ \\
\hline 3 & $-3,427.10$ & 31.68092 & $8.46 \mathrm{E}+31$ & 87.67737 & 90.05939 & 88.63239 \\
\hline 4 & $-3,414.83$ & 18.09057 & $1.21 \mathrm{E}+32$ & 87.99575 & 91.12216 & 89.24921 \\
\hline 5 & $-3,390.04$ & 33.46283 & $1.29 \mathrm{E}+32$ & 88.00106 & 91.87186 & 89.55298 \\
\hline 6 & $-3,364.99$ & 30.68595 & $1.41 \mathrm{E}+32$ & 87.99982 & 92.61500 & 89.85018 \\
\hline 7 & $-3,330.69$ & $37.73482^{*}$ & $1.27 \mathrm{E}+32$ & 87.76721 & 93.12677 & 89.91601 \\
\hline 8 & $-3,295.57$ & 34.24170 & $1.20 \mathrm{E}+32$ & $87.51422^{*}$ & 93.61816 & 89.96146 \\
\hline
\end{tabular}

* Indicates lag order selected by the criterion.

Source: own elaboration. 


\subsection{Results of the Co-integration Test}

In order to determine whether a short-run or long-run relationship exists between or among the variables in the study, it was very important to first estimate a system equation of a dynamic structure. The linkage among variables is a key factor of any study, as using variables without any relationship should lead to no results. A mechanism usually used to determine a long-run relationship is known as the co-integration test. The Johansen co-integration approach is one of the tests employed to detect if variables have a long-run relationship. The test uses eigen value transformation to detect a maximum correlation of linear combination among variables.

Table 3. Johansen Co-Integration Test Results

\begin{tabular}{|c|c|c|c|c|c|c|c|c|c|}
\hline \multicolumn{5}{|c|}{ Maximum Eigen test } & \multicolumn{5}{c|}{ Trace test } \\
\hline $\mathrm{H}_{0}$ & $\mathrm{H}_{1}$ & statistic & $\begin{array}{c}\mathrm{CV}(\mathrm{at} \\
5 \%)\end{array}$ & $\mathrm{p}$-value & $\mathrm{H}_{0}$ & $\mathrm{H}_{1}$ & statistic & CV (at 5\%) & p-value \\
\hline $\mathrm{r}=0$ & $\mathrm{r}=1$ & 45.855 & 33.877 & 0.0012 & $\mathrm{r}=0$ & $\mathrm{r} \geq 1$ & 90.0176 & 69.81889 & 0.0006 \\
\hline $\mathrm{r}=1$ & $\mathrm{r}=2$ & 22.165 & 27.585 & 0.2120 & $\mathrm{r} \leq 1$ & $\mathrm{r}=2$ & 44.1626 & 47.85613 & 0.1066 \\
\hline $\mathrm{r}=2$ & $\mathrm{r}=3$ & 11.253 & 21.132 & 0.6221 & $\mathrm{r} \leq 2$ & $\mathrm{r}=3$ & 21.9968 & 29.79707 & 0.2987 \\
\hline $\mathrm{r}=3$ & $\mathrm{r}=4$ & 8.5325 & 14.265 & 0.3271 & $\mathrm{r} \leq 3$ & $\mathrm{r}=4$ & 10.7436 & 15.49471 & 0.2277 \\
\hline $\mathrm{r}=4$ & $\mathrm{r}=5$ & 2.2110 & 3.8415 & 0.1370 & $\mathrm{r} \leq 4$ & $\mathrm{r}=5$ & 2.2110 & 3.841466 & 0.1370 \\
\hline
\end{tabular}

Note: Results were estimated using deterministic trend specification case 3.

Maximum Eigen and Trace tests indicate a single co-integrating equation at $5 \%$.

Source: own elaboration.

The results of the Johansen test of co-integration undertaken using the VAR approach of five variables are exhibited in Table 3. The null hypothesis suggests the absence of a long-run relationship or co-integration amid variables. Given that for both eigen value and trace test statistics exceed their critical values at the $5 \%$ level of significance (when $\mathrm{H}_{0}$ is $r=0$ ), it means that at least one cointegrating vector is present. For more than one cointegrating equation $\left(\mathrm{H}_{0}\right.$ is $r=1$ or $r \geq 1$ ), both eigen value and trace test statistics are less than the critical values at the $5 \%$ level of significance; suggesting that there is only one cointegrating equation. It is therefore concluded that there is a long-run relationship among the variables. In normalising coefficients and making one of the endogenous variables a function of the others, the following the long-run relationship equation is generated:

$$
L E M A N=18.126-3.0318 L C O N S+1.230 G O V S+1.033 I N V E S+0.00001 N E X P
$$

Equation 11 indicates the presence of a negative relationship between consumption and employment in manufacturing, as a $1 \%$ increase in consumption results in $3.0318 \%$ of job losses. However, there is a positive relationship in the relationship between job creation in the 
manufacturing sector and the other three components of aggregate spending. When government spending increases by $1 \%$, job creation in manufacturing increases by $1.230 \%$, and if there is a $1 \%$ increase in investment spending, manufacturing employment increases by $1.033 \%$. Nevertheless, the effect of net exports on manufacturing employment is almost insignificant. One million increases in net exports create $0.00001 \%$ jobs in the manufacturing sector. Joining the effect of net exports and consumption on employment in the manufacturing sector, this finding indicates that South Africans consume a large quantity of imported goods and services. Henceforth, a negative effect of consumption on employment and a nearly insignificant effect of net exports towards manufacturing employment as indicated in the equation 11.

\subsection{The speed of adjustment to the long-run equilibrium}

The presence of a long-run relationship among variables leads to the estimation of the Vector Error Correction Model (VECM). The results from this estimation are presented in Table 4. Considering that the error correction term has to be negative and significant, the ECT for manufacturing employment is the only equation to meet the requirement of adjustment to the long-run equilibrium. The VECM results suggest the absence of a short-run relationship among the variables. These results correspond to the outcome from the Grangers causality test, in which, besides the net exports, none of the variables is significant.

Table 4. Error Correction (ECT) Results

\begin{tabular}{|l|c|c|c|c|c|}
\cline { 2 - 5 } \multicolumn{1}{c|}{} & D(LEMAN) & D(LCONS) & D(LGOVS) & D(LINVES) & D(NEXP) \\
\hline ECT & -0.00489 & 0.001269 & 0.002511 & -0.000704 & 13249.99 \\
\hline S.E & -0.00209 & -0.00114 & -0.00157 & -0.00429 & -6869.38 \\
\hline T-Value & {$[-2.3442]$} & {$[1.1169]$} & {$[1.6012]$} & {$[-0.1640]$} & {$[1.9288]$} \\
\hline
\end{tabular}

Source: own elaboration.

When running a regression analysis using econometric techniques, there is room for making some mistakes which can lead to erroneous conclusions. Therefore, the normality test, serial correlation, and heteroscedasticity were used in the study in order to ensure the accuracy of findings. To achieve this objective, the null and alternative hypotheses were set and the results are represented in Table 5. 
Table 5. Results of Diagnostic Tests

\begin{tabular}{|l|c|c|c|c|}
\hline \multicolumn{1}{|c|}{ Test } & Ho & P-value & Decision & Conclusion \\
\hline Jarque-Bera & $\begin{array}{c}\text { Residuals are normally } \\
\text { distributed }\end{array}$ & 0.064 & Fail to reject $\mathrm{H}_{0}$ & Residuals are normally distributed \\
\hline LM Test & No Serial correlation & 0.798 & Fail to reject $\mathrm{H}_{0}$ & $\begin{array}{c}\text { There is no serial correlation } \\
\text { in the model }\end{array}$ \\
\hline White $(\mathrm{CT})$ & No Heteroscedasticity & 0.357 & Fail to reject $\mathrm{H}_{0}$ & $\begin{array}{c}\text { There is no heteroscedasticity } \\
\text { in the model }\end{array}$ \\
\hline
\end{tabular}

Source: own elaboration.

Since the results in Table 6 show that the VECM model passed all the necessary diagnostic tests, the conclusion is certainly that the results are reliable.

\subsection{Granger Causality Test}

Having found the long-run relationship among the variables, the next step is to test if these variables have a short-run relationship, and to determine the direction of causality. This can be achieved by undertaking the Granger causality test. Table 6 displays the summary of the results obtained from the Granger causality test. The results show that three of the four dependent variables can assist in predicting short-run employment in the manufacturing sector. However, investment spending does not cause short-run employment in the manufacturing sector. This makes sense, as it takes time for investment spending to create jobs. In addition, in this era of technology growth, a big share of investment is allocated to technology - which is not in favour of labour demand.

Table 6. Granger Causality Results (p-values)

\begin{tabular}{|l|c|c|c|c|c|}
\cline { 2 - 6 } \multicolumn{1}{c|}{} & \multicolumn{5}{c|}{ Regressand } \\
\hline \multicolumn{1}{c|}{ Regressor } & LEMAN & LCONS & LGOVS & LINVES & NEXP \\
\hline LEMAN & ------- & 0.114 & 0.806 & 0.983 & 0.737 \\
\hline LCONS & 0.092 & ------- & 0.053 & 0.881 & 0.654 \\
\hline LGOVS & 0.979 & 0.051 & ------ & 0.643 & 0.919 \\
\hline LINVES & $0.013^{*}$ & $0.000^{*}$ & 0.139 & ------- & 0.536 \\
\hline NEXP & 0.481 & 0.056 & $0.025^{*}$ & 0.783 & ------- \\
\hline
\end{tabular}

* Indicates the rejection of the null hypothesis at the $5 \%$ level of significance.

Source: own elaboration. 


\subsection{Impulse Response Function Analysis}

Impulse responses were undertaken to quantify the responsiveness of the variables to structural shocks or changes in the system. This was applied to each variable to determine its effect on the VECM system used by the study. That is, a unit shock was applied to each variable to determine its effects on the used VECM system. In other words, impulse responses provide information of reaction of one variable towards the changes or shocks in other variables.

Response to Generalized One S.D. Innovations
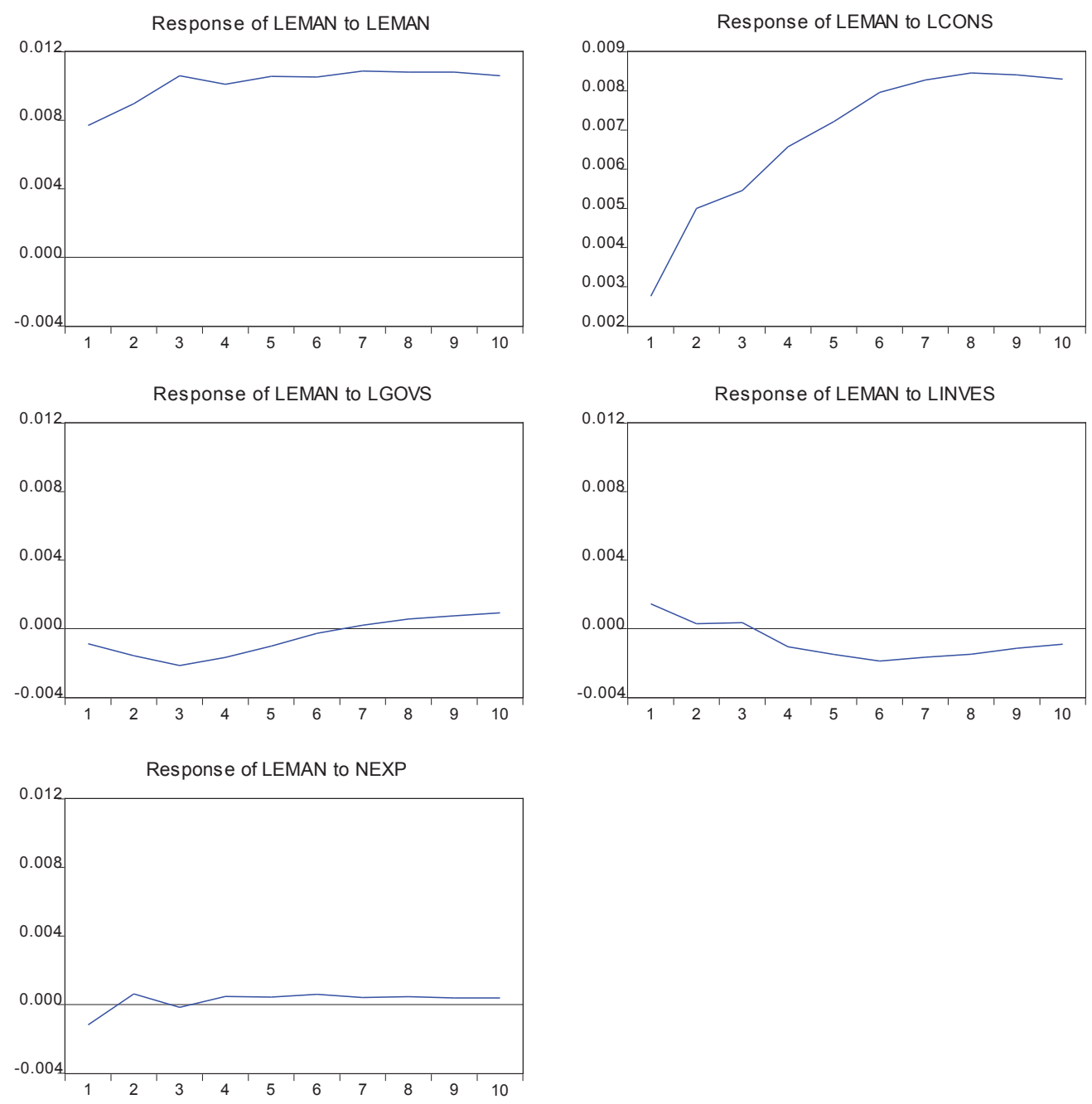

Figure 1. The Normalized Impulse Response Functions for Employment in Manufacturing sector

Source: own elaboration. 
A generalised impulse response is a better tool in interpreting impulse response of the VECM system, as it averages the past and present shock of variables in order to predict the future (Koop et al. 1996: 129). Using Y and X axes, the former represents percentage changes in a variable, while the latter indicates the time-length it takes a variable to respond to the change in the system. The generalised impulse response of employment in the manufacturing sector to the shock or innovation in consumption indicates an increase in employment from quarter 1 to 4 and then stabilises up to quarter 8 - where it starts declining again. This indicates that the effect of household consumption on job creation varies depending on the economic cycle and the source of goods to be consumed (imported or domestically manufactured). With regard to government spending, the generalised impulse function of employment in the manufacturing sector towards government spending indicates that job creation increased from quarter 1 upwards - from negative to positive. This is supported by the theories stating that every cent spent by government contributes to job creation in one way or another. Therefore, in the South African economy, there is a positive relationship between government spending and job creation.

Considering the GIRF of employment in manufacturing towards structural innovation in investment spending, the results in Figure 1 show a slight decline in employment from quarter 1 to quarter 4 - and they then stabilise and remain positive. This implies a constant and positive relationship between manufacturing employment and investment spending. Notwithstanding this, the outcome of manufacturing employment in respect of structural innovation in net exports, denotes a small decline in manufacturing jobs from quarters 1 to 2, and then stabilises although in the negative side. The outcome implies the insignificant effect of net exports on job creation in the South African manufacturing sector. This is not unexpected, as South Africa is a net import country rather than a net export one. Having explored the responsiveness of job creation in the manufacturing sector to the shocks in independent variables, it is necessary to analyse the responsiveness of these variables in respect of the shocks in the manufacturing employment. Endogenous changes of this variable are exhibited in Figure 2.

The generalised impulse response of consumption to the structural innovation in the manufacturing employment is negative. Manufacturing employment fluctuation results in consumption declining. The negative effect is small in the short-run, yet, as the time increases the effect becomes more serious. There is also a small decrease in consumption in quarters 1 to 5 , and then it goes down up to quarter 10. This makes sense as consumption depends on income, and usually employment means income; the more people are employed the higher is the consumption level. In respect to the responsiveness of government spending towards the changes in manufacturing employment, results in Graph 2 show that a change in employment 
leads to negative government spending, meaning that a positive shock in employment reduces government spending. This implies that a decrease in the number of workers reduces government income, and increases total government spending.

\section{Response to Generalized One S.D. Innovations}
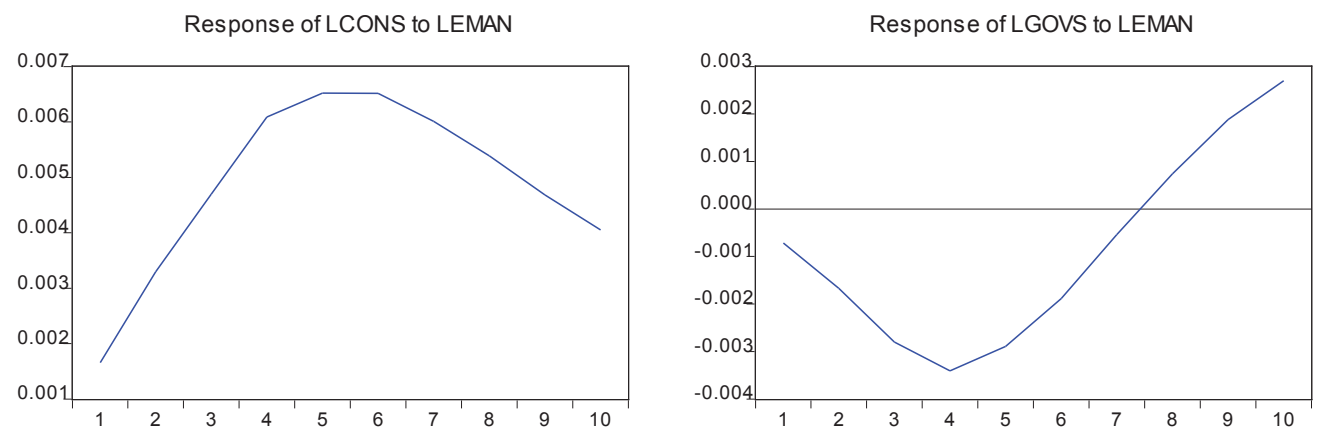

Response of LINVES to LEMAN

Response of NEXP to LEMAN
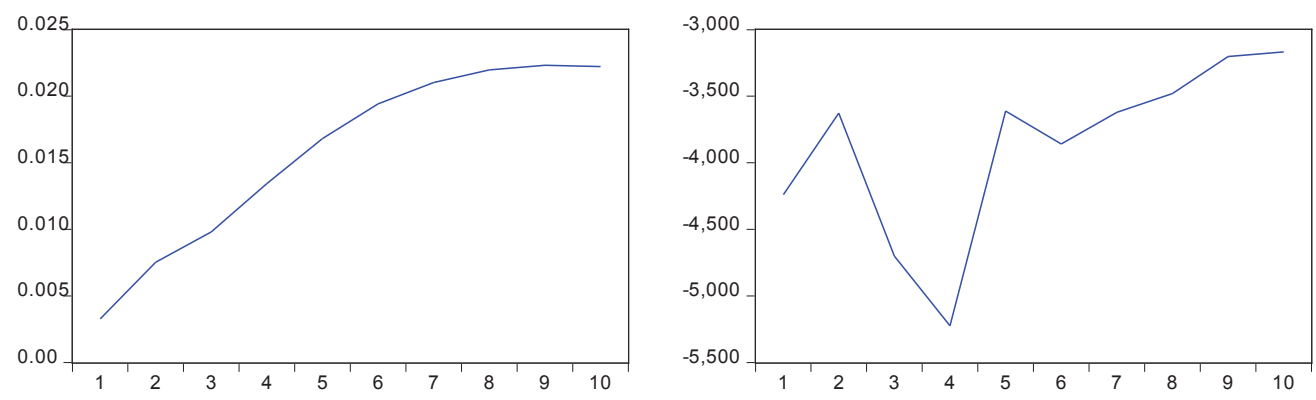

Figure 2. Impulse Responses of Consumption, Government Spending, Investment, and Net Export

Source: own elaboration.

The generalised responsiveness of investment spending to the changes in manufacturing employment shows that the structural innovation in manufacturing employment leads to a rise in investment spending up to quarter 5 where it reaches equilibrium, and then from quarter 8 it starts declining. That is, newly employed people invest more in a better standard of life in the future. As time goes by, they spend more on consumption than they invest. With regard to the responsiveness of total exports to the changes in employment, the result shows that from quarters 1 to 3 the shock in manufacturing employment increases net exports, and then they fluctuate up to quarter 6 where it reaches equilibrium and remains constant. 


\subsection{Forecasting Error Variance Decomposition}

The results in Table 7 represent the variance decomposition of each of the used variables over a 36-quarter timeframe - that is nine years. The result of each year is not presented - but rather every last quarter of the year. As is revealed in Table 7, the higher changes in manufacturing employment are caused by manufacturing employment itself (own shock). However, the own shock manufacturing employment decreases gradually, at the end of the first year (quarter four) the contribution on its own shock is $92 \%$ of the total shocks, while by the last quarter of year nine the contribution becomes around $73 \%$. The second variable to cause fluctuations in manufacturing employment is consumption, and its contribution increases gradually from $6 \%$ at the end of the first year to $11 \%$ at the end of the ninth year. Like consumption, government spending and net exports cause employment in the manufacturing sector to increase gradually - from $1.31 \%$ at the end of the first year to $9.13 \%$ at the end of the ninth year and 0.82 to 0.3 .23 in net exports, respectively. Lastly, the contribution of investment spending to employment in manufacturing fluctuations is almost insignificant, from 0.03 in the fourth quarter to 0.34 in the last quarter of year nine.

Table 7. Forecast Error Variance Decomposition

\begin{tabular}{|c|c|c|c|c|c|c|}
\hline Period & S.E. & EMAN & CONS & GOVS & INVES & NEXP \\
\hline 1 & 0.0077 & 100.000 & 0.000 & 0.000 & 0.000 & 0.000 \\
\hline 4 & 0.0198 & 91.971 & 5.869 & 1.314 & 0.028 & 0.815 \\
\hline 8 & 0.0319 & 81.682 & 10.733 & 5.667 & 0.035 & 1.880 \\
\hline 12 & 0.0408 & 77.700 & 10.816 & 8.788 & 0.121 & 2.572 \\
\hline 16 & 0.0475 & 76.734 & 10.427 & 9.643 & 0.267 & 2.927 \\
\hline 20 & 0.0529 & 76.658 & 10.287 & 9.628 & 0.334 & 3.090 \\
\hline 24 & 0.0579 & 76.761 & 10.249 & 9.477 & 0.345 & 3.166 \\
\hline 28 & 0.0626 & 76.823 & 10.292 & 9.337 & 0.342 & 3.203 \\
\hline 32 & 0.0670 & 76.803 & 10.415 & 9.222 & 0.337 & 3.220 \\
\hline 36 & 0.0711 & 76.719 & 10.589 & 9.130 & 0.335 & 3.225 \\
\hline
\end{tabular}

Source: own elaboration.

\section{Policy Implications and Conclusions}

The study analyses the interaction between effects of aggregate expenditure on the employment in the manufacturing sector, and how the former responds to the changes in the latter. The results of the analysis proved the presence of a long-run relationship between aggregate expenditure and job creation in the manufacturing sector. Each component of total 
spending plays its role in improving manufacturing employment in the South African economy, with jobs created through spending having a positive impact on future spending. Export and consumption have a major impact on manufacturing employment, and government spending also plays its part. Although investment spending contributes to long-run job creation, its impact is not as strong as the previous three components of aggregate expenditure (consumption, exports, and government spending). In the same context, investment spending does not create jobs in short-run yet other variables of aggregate expenditure create short-run employment in the manufacturing sector.

Since aggregate expenditure, in general, creates short-run and long-run jobs in the South African manufacturing sector, government and the private sector should collaborate and complement each other in order to improve spending in a wise way - as unwise spending can cost the economy and destroy jobs rather than create them. Different theories suggest that investment spending not only creates jobs, but that it also sustains the existing jobs. Henceforth, it is important to support or increase investment spending in South Africa, in order to create more and sustainable jobs in the South African economy.

\section{References}

Afonso, A., Sousa, R.M. (2012). The macroeconomic effects of fiscal policy. Applied Economics, 44 (34), 439-54.

Amjad, R. (2005). Pakistan's poverty peduction strategy: Why employment matters. The Lahore Journal of Economic, 10, 144-178.

Athukorala, P.C., Santosa, B.H. (1996). Gains from export growth: Do linkages matter? Retrieved from: https://digitalcollections.anu.edu.au/handle/1885/40134 (17.07.2016).

Autor, D.H., Dorn, D., Hanson, G.H. (2013). The China syndrome: Local labour market effects of import competition in the United States. American Economic Review, 103(6), 2121-2168.

Beard, T.R., Ford, G.S., Kim, H., Spiwak, L.J. (2011). Can government spending get America working again? An empirical investigation. Phoenix Center Policy Bulletin, 31, 1-15.

Bentolila, S., Ichino, A. (2000). Unemployment and consumption: Are job losses less painful near the Mediterranean? Working paper, no. 0010. CEMFI. 
Bertolis, D.E., Hayes, M. (2014). An investigation into South African general equity unit trust performance during different economic periods. South African Actuarial Journal, 14, 73-99.

Blanchard, O.J., Perotti, R. (2002). An empirical characterization of the dynamic effects of changes in government spending and taxes on output. Quarterly Journal of Economics, 117, 1329-1368.

Bobeica, E., Esteves, P.S., Rua, A., Staehr, K. (2016). Exports and domestic demand pressure: a dynamic panel data model for the euro area countries. Review of World Economics, 152 (1), 107-125.

Chamley, C. (2014). When demand creates its own supply: saving traps. Review of Economic Studies: 2 (81), 651-680.

Coenen, G., Straub, R. (2005). Does government spending crowd in private consumption? Theory and empirical evidence for the euro area. International Finance, 8 (3), 435-470.

Cray, A., Nguyen, T., Pranka, C., Schildt, C., Sheu, J., Whitcomb, E.R. (2011). Job Creation: A Review of policies and strategies. IRLE Working paper, 11 (105), 1-57.

Dinh, H.T., Palmade, V., Chandra, V., Cossar, F. (2012). Light Manufacturing in Africa: Targeted Policies to Enhance Private Investment and Create Jobs. Washington D.C.: The World Bank.

Dizaji, M., Badri, A.K. (2014). The Effect of Exports on Employment in Iran's Economy. Merit Research Journal of Art, Social Science and Humanities, 2 (6), 081-088.

Emilia, H. 2008. The influence of final consumption on employment in Romania. Annals of the University of Oradea. Economic Science Series, 17 (2), 870-875.

Engle, R., Granger, C. (1987). Cointegration and error correction: Representation, estimation and testing. Econometrica: Journal of the Econometric Society, 55 (1), 251-276.

Feenstra, R.C., Hong, C. (2007). Chang Hong China's exports and employment. NBER Working paper No. 13552. Cambridge.

Finn, M.G. (1998). Cyclical effects of government's employment and goods purchases. International Economic Review (39), 635-657.

Fukase, E. (2013). Export liberalization, job creation, and the skill premium: evidence from the US-Vietnam bilateral trade agreement (BTA). World Development, 41, 317-337.

Galí, J., López-Salido, J.D., Vallés, J. (2005). Understanding the effects of government spending on consumption. Retrieved from: http://crei.cat/people/gali/911.pdf (7.06.2016).

Gurgul, H., Lach, T. (2011). The interdependence between energy consumption and economic growth in the Polish economy in the last decade. Ekonomia Menedzerska, 9, 25-48.

Habanabakize, T., Muzindutsi, P.F. (2015). Time series analysis of interaction between aggregate expenditure and job creation in South Africa. Journal of Governance and Regulation, 4 (4), 649-657. 
Holden, S., Sparrmany, V. (2016). Do government purchases affect unemployment? Retrieved from: http://folk.uio.no/sholden/wp/fiscal-U.pdf (11.03.2016).

Iacovoiu, V.B. (2012). Impact of capital investments on unemployment in the context of economic crisis. The case of Romania. Economic insights - trends and challenges, 1 (64), 36-47.

Kenyon, P. (1997). Infrastructure spending and unemployment: government responsibility for growth and jobs. Australian Economic Review, 30 (4), 421-432.

Keynes, J.M. (1936). The General Theory of Employment, Interest and Money. London: Macmillan.

Kiyota, K. (2011). Trade and employment in Japan. OECD Trade Policy Working Papers, no. 127. OECD Publishing.

Kiyota, K. (2016). Exports and Employment in China, Indonesia, Japan, and Korea. Asian Economic Papers, 15 (1), 1-38.

Lamo, A., Pérez, J.J., Schuknecht, L. (2007). The cyclicality of consumption, wages and employment of the public sector in the Euro area. Working Paper Series.

Leigh, A., Neill, C. (2011). Can national infrastructure spending reduce local unemployment? Evidence from an Australian roads program. Economics Letters, 113 (2), 150-153.

Loizides, J., Vamvoukas, G. (2005). Government expenditure and economic growth: evidence from trivariate causality testing. Journal of Applied Economics, 8 (1), 125-152.

Los, B., Timmer, M.P., de Vries, G.J. (2015). How important are exports for job growth in China? A demand side analysis. Journal of Comparative Economics, 43 (1), 19-32.

Mahmood, H., Khalid, S. (2013). Fiscal Policy for Growth and Employment Generation in Pakistan. Academic Research International, 4 (6), 372-381.

Maisonnave, H., Mabugu, R., Chitiga, M., Robichaud, V. (2013). Analysing Job Creation Effects of Scaling Up Infrastructure Spending in South Africa. Cahier de recherche/Working paper, 10 (13), 1-28.

Majumdar, A., Borbora, S. (2015). Production Linkages between the Formal and the Urban Informal Manufacturing Sectors: A Case Study in Assam. Review of Integrative Business and Economics Research, 4 (1), 75-94.

Munnell, A.H. (1992). Policy Watch: Infrastructure Investment and Economic Growth. The Journal of Economic Perspectives, 6 (4), 189-198.

Nguyen, T.K. (2015). Manufacturing exports and employment generation in Vietnam. Southeast Asian Journal of Economics, 3 (2), 1-21.

Nicholson, J.R., Noonan, R. (2014). Manufacturing Since the Great Recession. Economics and Statistics Administration. U.S. Department of Commerce. 
Psaltopoulos, D., Skuras, D., Thomson, K.J. (2011). Employment effects of private investment initiatives in rural areas of southern Europe: a regional SAM approach. Agricultural Economic Review, 12 (1), 50-61.

Ramey, V.A. (2012). Government spending and private activity. San Diego and NBER: University of California.

Rotman, D. (2013). How technology is destroying jobs. Technology Review, 16 (4), 28-35.

Said, M., Elshennawy, A. (2010). The Impact of Trade Liberalization on Manufacturing Employment and Wages in Egypt 1990-2007. International Research Journal of Finance and Economics, 46, 138-159.

SARB (2015). South African Reserve Bank. Quarterly Bulletin December 2015.

Schettkat, R., Salvedra, W. (2004). Demand patterns and employment growth: consumption and services in France, Germany, the Netherlands, the United Kingdom and the United States. Work Programme.

Shi, A., Michelitsch, R. (2013). Assessing private sector contributions to job creation: IFC open source study. IFC, Washington.

Small Enterprise Development Agency, SEDA (2012). Analysis of the Needs, State and Performance of Small and Medium Businesses in the Agriculture, Manufacturing, ICT and Tourism Sectors in South Africa. Retrieved from: http://www.seda.org.za/Publications/ Pages/Annual-Reports.aspx (July 2016).

Sousa, N., Rueda-Cantouche, J., Arto, I., Andreoni, V. (2012). Extra-EU exports and employment. DG Trade Chief Economist Note: European Commission.

Stanlib (2013). SA Consumer spending to remain subdued over the coming year. Retrieved from: http://www.stanlib.com/EconomicFocus/Pages/SAConsumerspendingtoremainsubduedoverthecomingyear.aspx (13.06.2016).

StatSA (2015). Statistics South Africa. Quarterly Labour Force Survey. Pretoria.

Tcherneva, P.R. (2008). Keynes's approach to full employment: aggregate or targeted demand? Working Paper no. 542. Levy Economics Institute.

Toossi, M. (2002). Consumer spending: an engine for U.S. job growth. Monthly Labour Review, $1-13$.

Tschetter, J. (2010). Exports support American jobs. International Trade Research Report. Washington DC: International Trade Administration. 